\title{
Modlitwa drogą do świętości
}

Ks. dr Krzysztof M. BiA£OWĄS

Postulator Rzymski, Kongregacja ds. Świętych, Watykan

„Modlitwa jest dla mnie wzniesieniem serca, prostym spojrzeniem ku Niebu, okrzykiem wdzięczności i miłości zarówno w cierpieniu, jak i radości". św. Teresa od Dzieciątka Jezus

Modlitwa dla chrześcijanina jest rozmową $\mathrm{z}$ Bogiem. Zwracamy się do Niego wtedy, kiedy nasze serce przepełnione jest radością, gdy jest nam smutno, kiedy spotyka nas coś niedobrego. Chrześcijanin pragnie, by Bóg był obecny w jego życiu w każdej sytuacji. Biorąc pod uwagę cel modlitwy, możemy ją podzielić na modlitwę uwielbienia, dziękczynienia, przebłagania i prośby. Katechizm Kościoła katolickiego mówi: „Modlitwa ustna jest niezbędnym elementem życia chrześcijańskiego. Uczniów, przyciąganych cichą modlitwą Nauczyciela, uczy On modlitwy ustnej: «Ojcze nasz»" (n. 2701). Pismo Święte dostarcza wielu przykładów ukazujących ludzi zwracających się na modlitwie do Boga ${ }^{1}$.

${ }^{1}$ Izraelici starali się zbliżyć do Boga w modlitwie. W Psalmach znajdziemy pragnienie wznoszenia serca do Boga w każdej chwili: nie tylko 
Najważniejszym z nich jest Jezus Chrystus modlący się modlitwami liturgicznymi w synagodze ${ }^{2}$, wypowiadający modlitwę błogosławieństwa Ojca (Mt 11, 25-26; 14, 19)3 czy trwogi w Getsemani (Mk 14, 36). Modlitwa biblijna jest osobowa i ma charakter dialogu. Jest miejscem spotkania dwóch osób, Boga i człowieka, które się kochają i wzajemnie poszukują. Podstawowe elementy określające chrześcijańską modlitwę to: świadomość spotkania, miłość, tęsknota, dyspozycyjność wobec Boga. Gdy Bóg mówi, to człowiek słucha i odpowiada. Kiedy Bóg działa, człowiek z Nim współpracuje. Człowiek mówi do Boga z głębi siebie, jest to modlitwa „serca”, czyli taka, która wznosi się z samego centrum osoby, z głębi życia, porusza się w sferze dóbr duchowych, ale

podczas modlitwy w świątyni (Ps 55,18 ), ale siedem razy w ciągu dnia (Ps 119, 64); więcej nawet: przez cały dzień (Ps 119, 57) - od wczesnego ranka, a także w nocy (Ps 5, 4; 77, 3). Psalmista pragnie kroczyć zawsze w obecności Boga (Ps 88, 10; 16, 8). Żydzi żyjący za czasów Jezusa - przynajmniej mężczyźni - mieli obowiązek rano i wieczorem odmawiać Szema Israel, które było swego rodzaju wyznaniem wiary. O trzeciej po południu wszyscy (także niewolnicy, kobiety i dzieci) odmawiali Osiemnaście błogosławieństw. Ponadto były ustalone specjalne modlitwy dla każdego posiłku, na dzień szabatu, na święta, na okresy postu oraz z okazji każdego ważnego wydarzenia w życiu.

2 Jezus uczestniczył w rytualnych modlitwach szabatu, odprawianych w synagodze, a także w modlitwach w świątyni z okazji wielkich uroczystości. Zapewne, jak każdy Żyd w tamtych czasach, również Jezus odmawiał przepisane modlitwy. Por. Mk 14, 20; Mt 26, 30.

${ }^{3}$ Ewangeliści podają, że Jezus odmawiał modlitwę błogosławieństwa: w czasie rozmnożenia chlebów i ryby (Mk 6, 41; 8, 7; Mt 14, 19; 15, 36; Łk 9, 16; J 6, 11); kiedy pobłogosławił dzieci (Mk 10, 16); w czasie Ostatniej Wieczerzy, gdy uroczyście pobłogosławił chleb i wino (Mk 14, 22-23; Łk 22, 19-20; Mt 26, 26-27); po zmartwychwstaniu powtórzył ten akt w Emaus (Łk 24, 50-51); po raz ostatni pobłogosławił uczniów w momencie wniebowstąpienia (Łk 24, 51). 
i w całości życia. Ta rozmowa jest realna i prawdziwa; bywa, że przybiera postać dyskusji lub sporu. Rozmowa z Bogiem porusza się między dwoma biegunami: transcendencją i immanencją ${ }^{4}$, bliskością i oddaleniem, poufałością i bojaźnią. Modlitwa Nowego Testamentu ma charakter trynitarny, jest określonym i osobistym odniesieniem do Boga Ojca, Pana Jezusa i Ducha Świętego. Ostatecznym celem modlitwy jest zawsze Ojciec, ale przez Chrystusa i w Duchu Świętym.

Modlitwa biblijna jest więc głęboko osobowa, angażuje całego człowieka i domaga się od niego szczerości, jest zarówno wspólnotowa, jak i kościelna. Jeśli modlitwa jest dialogiem, to czy jest w niej miejsce na milczenie? W Biblii spotyka się Boga, który milczy. W Psalmie 22, 2 czytamy: „Boże mój, Boże mój, czemuś mnie opuścił?”. Ta skarga ubogiego Żyda stała się modlitwą Chrystusa na krzyżu. Doświadczenie milczenia Boga obejmuje całe życie religijne, ale właśnie w modlitwie to doświadczenie jest wyraziste. Najważniejszymi formami modlitwy biblijnej są błagania i uwielbienia. Człowiek szuka Boga, błaga Go w swoich potrzebach i przeprasza za swoje niewierności i grzechy, wielbi za Jego cuda. Modlitwa jest zawsze spojrzeniem zarazem wertykalnym i horyzontalnym, nigdy tylko jednym lub drugim. Szukamy oblicza Boga i jesteśmy odsyłani do stworzenia i historii: tutaj są Jego ślady, znaki Jego miłości i Jego miłosierdzia. Pytamy o życie i jesteśmy odsyłani do Boga i Jego tajemnicy ${ }^{5}$.

${ }^{4}$ Immanencja (filozof.) - pozostawanie wewnątrz czegoś lub niezależność bytowa od czynnika zewnętrznego; https://sjp.pwn.pl/sjp/immanencja;2465829.html (27.01.2019).

${ }^{5}$ Por. R. Cantalamessa, B. Maggioni, Modlić się w Duchu i prawdzie. Modlitwa według Biblii, tłum. K. Stopa, Kraków 2011. 
Powróćmy do modlitwy Jezusa, która bywała niekiedy krótkim błogosławieństwem, czasem wielogodzinną kontemplacją, nawet wielodniowym odosobnieniem i postem. Jezus, poproszony przez uczniów, uczy nas wszystkich modlitwy „Ojcze nasz”. Z Ewangelii dowiadujemy się, że Bogu należy oddawać cześć w Duchu i w prawdzie (J 4, 23-24), bez nadmiaru słów (Mt 6, 7) czy zewnętrznych praktyk (Mk 7, 6), najlepiej w ukryciu (Mt 6, 6) - chodzi bowiem jedynie o wzniesienie serca ku Bogu (Mt 6, 6) i słuchanie Jego słowa. Tylko to jest rzeczą niezbędną (por. Łk 10, 39-42).

To krótkie słowo wstępne, oparte na Biblii, KKK, pracy Ignacego de la Potterie Modlitwa Jezusa oraz książce Raniera Cantalamessy i Brunona Maggioniego Modlić się w Duchu i prawdzie. Modlitwa według Biblii, wprowadza nas w rozważania nad znaczeniem modlitwy w drodze do świętości.

Praca postulatora oparta jest na zbieraniu dokumentów ukazujących drogę do świętości kandydatów na ołtarze. Analiza wszystkich zebranych materiałów pozwala stwierdzić, jak ważną rolę w życiu tych ludzi odgrywała modlitwa niezależnie od czasów, w których żyli. Oto krótka synteza modlitwy św. Franciszka z Asyżu, bł. Dominika Spadafory i św. o. Pio.

Działalność św. Franciszka Bernardone, biedaczyny z Asyżu (1182-1226) wypełniona była miłością do Boga i ludzi oraz wszelkich stworzeń. Mottem działalności Franciszka stało się pokazywanie ogromu miłości, jaką obdarzył nas Bóg, wydając swego Syna na mękę dla naszego zbawienia. To krzyk wyrywający się z głębi serca, że Miłość nie jest kochana. Innym zostawił tropienie herezji, sądy i potępienia. On - Franciszek - kochał i wierzył w potęgę 
miłości płynącej od Boga. To fascynuje wszystkich, którzy zetknęli się z pismami o Franciszku czy tekstami jego samego. Lektura fragmentów biografii św. Franciszka dostarcza szczegółowych informacji na temat życia, działalności i przesłania, jakie niósł z sobą światu Biedaczyna z Asyżu.

$\mathrm{Na}$ uwagę zasługują przede wszystkim części poświęcone modlitwie i kontemplacji. Łączy je głębia wejścia w prawdy ewangeliczne i umiejętność słuchania słów Bożych. „Cały był nie tylko modlącym się, co samą modlitwą"6. Franciszek modlił się wszędzie i zawsze, modlitwa ogarniała Biedaczynę proszącego, by: „nie gasić ducha świętej modlitwy i pobożności, któremu powinny służyć wszystkie sprawy doczesne"7, „wszędzie, na każdym miejscu, o każdej godzinie i o każdej porze, codziennie i nieustannie wierzmy wszyscy szczerze i pokornie nośmy w sercu i kochajmy, czcijmy, uwielbiajmy, służmy, chwalmy i błogosławmy".

W Pismach znajduje się kilka modlitw napisanych przez Franciszka. Mają one charakter trynitarny, co znaczy, że są skierowane do Ojca, przez Syna i w Duchu Świętym. Są to: Modlitwy pochwalne, Zachęta do uwielbienia Boga, Uwielbienie Boga Najwyższego, Pieśń słoneczna albo pochwała stworzeń. Zawierają one uwielbienie, adorację, podziw i dziękczynienie dla Stwórcy za jego wielkość, świętość, dobroć i dar zbawienia. Biedaczyna całym swym sercem nawołuje wszystko, co żyje - ale także rzeczy nieożywione, stworzone przez Boga - do oddania Najwyższemu czci i uwielbienia.

\footnotetext{
${ }^{6}$ Tomasz z Celano, Żywot drugi, 95.

${ }^{7}$ Reguła zatwierdzona, 5, 2.

${ }^{8}$ Reguła niezatwierdzona, 23, 11.
} 
Osobną część stanowią modlitwy skoncentrowane na Jezusie. W Testamencie zawarta jest modlitwa poświęcona Chrystusowi i Jego obecności w Najświętszym Sakramencie. Fragment ten wart jest zacytowania ze względu na ukazanie roli Kościoła w oddawaniu czci Bogu; roli, którą próbuje się mu odebrać: „Wielbimy Cię, Panie Jezu Chryste, tu i we wszystkich kościołach Twoich, które są na całym świecie i błogosławimy Tobie, żeś przez Krzyż Twój świat odkupić raczył”.

Franciszek uważał, że wzrok ciała nie jest potrzebny wierze, wskazywał na konieczność posiadania wzroku duchowego. Oczy ducha widzą Ciało i Krew Chrystusa. „Jak [Syn Boży] ukazał się świętym Apostołom w rzeczywistym ciele, tak i teraz ukazuje się nam w świętym Chlebie. I jak oni wzrokiem cielesnym widzieli tylko Jego Ciało, lecz wierzyli, że jest Bogiem, ponieważ oglądali Go oczyma cielesnymi, starajmy się dostrzegać i wierzmy mocno, że jest to Jego żywe i prawdziwe Najświętsze Ciało i Krew"g. Adoruje on Mękę Chrystusa poprzez zebrany przez siebie zbiór psalmów zawarty w Oficjum o Męce Pańskiej.

W zbiorze Pism św. Franciszka znajdują się dwie modlitwy poświęcone Maryi, współodkupicielce, którą Jezus Chrystus dał nam za Matkę. Jedna z tych modlitw, to antyfona odmawiana przy wszystkich godzinach Oficjum o Męce Pańskiej, druga to Pozdrowienie Błogosławionej Maryi Dziewicy. Obie te modlitwy świadczą o głębokim przywiązaniu Franciszka do Maryi. Tak bardzo kochał on maleńki ko-

9 Testament św. Franciszka [polski przekład w:] Święci Franciszek i Klara z Asyżu, Pisma. Wydanie łacińsko-polskie, Kraków-Warszawa, 2002, s. $215-219$.

18 · Ks. dr Krzysztof M. Białowąs 
ściółek Matki Bożej Anielskiej - Porcjunkulę. To we wnętrzu tego kościoła narodził się zakon, to w nim przyszły święty żegnał się z braćmi, by odejść do Pana. Przekazał potomnym troskę nad tym miejscem, bo wierzył, że właśnie tam Bóg będzie szczególnie im błogosławił.

Franciszek szukał również wstawiennictwa świętych, zarówno Starego, jak i Nowego Testamentu. Nie zapominał o aniołach, szczególnie o Michale Archaniele. To Jemu poświęcał posty. W czasie jednego z nich został obdarzony największym skarbem - współuczestnictwem w cierpieniu Jezusa Chrystusa - stygmatami.

Wraz z upływem życia zakonnego św. Franciszka można zauważyć pewne przemiany w charakterze modlitwy. W pierwszych modlitwach nad uwielbieniem przeważają błagania i prośby (Modlitwa odmówiona przed krucyfiksem). W okresie późniejszym dominują uwielbienie, chwała, kontemplacja najwyższego Boga. Modlitwy z tego okresu mają charakter bardziej biblijno-liturgiczny. $\mathrm{Na}$ bazie Pisma Świętego tworzy: Modlitwy pochwalne odmawiane przy wszystkich godzinach, Zachętę do uwielbiania Boga, wreszcie Oficjum o Męce Pańskiej, które ma charakter biblijno-liturgiczny. Tutaj również możemy zakatalogować Wykład modlitwy Ojcze nasz. Franciszek wzbogaca ją o osobiste treści, sugerowane wyraźnie przez słowo Boże. W tym czasie w modlitwie pojawia się liczba mnoga. Świadczy to o odczuwaniu przez Franciszka różnorakich potrzeb wszystkich ludzi. To w ich imieniu się modli. Pieśń słoneczna w największym stopniu oddaje charakter i treść modlitwy św. Franciszka.

Drugi człon modlitw, kontemplacja, jest bardzo osobisty, prosty i skomplikowany zarazem. Ukazuje etapy wzno- 
szenia się Franciszka do Boga - każdy, kto stara się iść śladami Mistrza, odkryje swoją drogę w oparciu o mistyczną drogę ku jedynej miłości Biedaczyny z Asyżu, ku Jezusowi Chrystusowi. Franciszek nie lubił teorii, tylko szczere działanie - czy to w modlitwie, czy też w posłudze bliźnim. Należy przeczytać i przemodlić jego drogę, by pójść swoją, ale warto iść za jego przykładem, by osiągnąć szczęście wieczne i oglądać oblicze Boga. On, Franciszek, dostąpił tego zaszczytu tu, na ziemi, dzięki systematycznemu wznoszeniu się na wyżyny modlitwy; my możemy osiągnąć to w przyszłym życiu.

Modlitwa Franciszka była dialogiem. Tomasz z Celano napisał: „Tam odpowiadał Mu jako sędziemu, błagał Go jak ojca, rozmawiał jak z przyjacielem, cieszył się jak z oblubieńcem"10.

Inną cechą jego modlitwy był minimalizm słów, przy wyniesieniu do maksimum uczucia i myśli. Wzywał z szacunkiem imienia Jezus, które oznacza „Pan zbawia”. Na Alwerni Franciszek mówił: „Ktoś Ty jest, najsłodszy Boże mój? Któżem ja, najpodlejszy robak i bezużyteczny sługa Twój?”. Brat Bernard widział modlącego się Franciszka, który powtarzał ciągle aż do rana: „Boże mój, Boże mój” i nic więcej. Biedaczyna często też wymawiał słowa: „Boże, bądź miłościw mnie grzesznemu”, a także „Bóg mój i wszystko!”. Posługiwał się również urywkami z psalmów i wersetami z Pisma Świętego. Posyłając w świat braci, żegnał ich słowami: „zrzuć swą troskę na Pana, a On cię podtrzyma” (Ps 55, 23). Zdanie to zawiera ideę przewodnią franciszkańskiego życia. Bracia, udając się w daleką drogę, mieli być bezgranicznie oddani Opatrzności Bożej.

${ }^{10}$ Tomasz z Celano, Żywot drugi, 95. 
Modlitewnikiem dla św. Franciszka była Biblia, to w Piśmie Świętym widział Ojca przemawiającego do dzieci i Jego syna - Chrystusa przemawiającego do braci. Jezus jest Słowem Ojca, który przemawia do nas przez Krzyż. Krzyż to myśli, uczucia, modlitwa, medytacja, towarzyszył mu wszędzie. „Kiedy bracia w Rivotorto trwali na modlitwie i nie mieli jeszcze ksiąg kościelnych, aby mogli śpiewać liturgiczne modlitwy dnia, rozważali dniem i nocą księgę Krzyża, ciągle się w nią wpatrując, pouczeni przykładem i słowami Ojca, który ustawicznie mówił im o Krzyżu Chrystusowym" (Życ.W., 4.3).

Błogosławiony Dominik Spadafora OP (1450-1521) urodził się na Sycylii, zmarł w Monte Cerignone. Przedstawiciel wpływowej rodziny szlacheckiej, został kaznodzieją z własnego wyboru. Oddał się na służbę Chrystusowii Kościołowi. Rozumiał, czym jest kapłaństwo, znał obowiązki dominikanina, dla którego wierność Ewangelii polega na miłości ${ }^{11}$ rozumianej jako niesienie Dobrej Nowiny i dzielenie się owocami kontemplacji.

Świadomy ogromu łask płynących ze stołu eucharystycznego o. Dominik pragnął, by spływały one na jego współbraci i wiernych. W kościele Matki Bożej Łaskawej w Monte Cerignone, w którym spędził prawie trzydzieści lat, codziennie słychać było śpiewaną mszę świętą oraz oficjum $^{12}$.

W pierwszej rozbudowanej biografii Dominika Spadafory z 1744 roku spotykamy się z jego „codzienną jaśniejącą

\footnotetext{
${ }^{11}$ Suma teologiczna, II, q. 184, a. 1.

${ }^{12}$ Vita et Miracoli del Beato Maestro Domenico Spada Fora. Manoscritto; G. Ronconi, Vita del Beato Domenico Spadafora Domenicano.
} 
żarliwością” w czasie odprawianej mszy świętej („che dalla Messa, quale celebrava quotidianamente con raro fervore" $)^{13}$. Żywa wiara budowała żywy Kościół. W XVI-wiecznym manuskrypcie ${ }^{14}$ i późniejszych biografiach ${ }^{15}$ kościół i klasztor w Monte Cerignone ukazane są jako miejsca rozbrzmiewające modlitwą, promieniejące świętością.

Będąc sługą liturgii, poprzedzał ją medytacją. Starał się, aby msza święta uświęcała ludzkie dusze. „Kapłan czuł, że odprawianie Mszy świętej i udzielanie sakramentów wznosiły go aż do Chrystusa, i tak wszystko wykonywał z głębokim oddaniem. A kiedy z ambony głosił słowo Boże, obietnice Bożego Nauczyciela przeradzały się w rzeczywistość: «Gdyż nie wy będziecie mówili, lecz Duch Ojca waszego, będzie mówił przez was»"16.

Istnieją zapisy z pierwszych lat kapłaństwa Dominika w Palermo mówiące, jak po ubiczowaniu swego ciała „tak umęczony przykrywał krwawiące ramiona szorstką wełną habitu i szedł do kościoła i tam spędzał długie godziny, ado-

13 G.B.M. Contarini, Vita del B. Domenico Spadafora de' Predicatori, Urbino 1744, [w:] AGOP, Sessione X. 1001, documentum n. 8, s. 170 (tłum. własne).

${ }^{14}$ Vita et Miracoli..., dz. cyt.; G. Ronconi, Vita del Beato Domenico Spadafora Domenicano, dz. cyt.

${ }^{15}$ D.M. Marchese, Vita del Beato Domenico Spadafora, [w:] Sacro Diario Domenicano, t. 6, Napoli 1681, s. 153-154, za: Confirmationis Cultus ab immemorabilis tempore praestiti Dominico Spadafora sacerdoti professo Ordinis Praedicatorum Beato Nuncupato, Positio Super Casu Exepto, Roma 1920; A. Mongitore, Vita del B. Domenico Spadafora Domenicano, [w:] Palermo santificato dalla vita dei suoi Cittadini-Vita dei Santi e dei Beati Palermitani, 1708; G.B.M. Contarini, Vita del B. Domenico..., dz. cyt.; R. Diaccini, Vita del..., dz. cyt.

${ }^{16}$ R. Diaccini, Vita del..., dz. cyt., s. 56. 
rując Jezusa w Najświętszym sakramencie aż do poranka"17. Eucharystyczne zjednoczenie z Trójcą Przenajświętszą było „chwałą i radością jego serca”18.

Chrystus był dla niego drogą, prawdą i życiem (por. J 14, 6). Medytacja Jego męki i śmierci, kroczenie królewską drogą krzyża ${ }^{19}$ widoczne były w całym jego życiu. Starał się czerpać nauki płynące z „katedry krzyża”20. Nauka krzyża (scientia crucis) nie jest teoretyczną nauką, którą można przekazać przy pomocy wykładu. Zdobywa się ją przez całe życie i nigdy nie możemy powiedzieć, że o krzyżu wiemy już wszystko. Naukę tę zdobywa się tylko wtedy, gdy się samemu do głębi doświadczy krzyża. Tak też czynił Dominik Spadafora. Ta „wspólna droga krzyżowa” rozpoczęła się dla młodego Spadafory w Palermo. „Stawiając pierwsze kroki w Zakonie, stał się pełnym poświęcenia i zapału nowicjuszem, dążącym do osiągnięcia ideału dominikańskiego poprzez modlitwę, ścisłe przestrzeganie reguły i umartwianie się"21. „Kiedy pod koniec dnia zmęczony trudami apostolstwa wracał do swej celi (...), klęcząc przed krzyżem biczował (...) swe członki aż do krwi"22. W tamtejszym klasztorze znajduje się obraz przedstawiający błogosławionego klę-

${ }^{17}$ R. Diaccini, Vita del..., dz. cyt., s. 21; por. G.B.M. Contarini, Vita del B. Domenico..., dz. cyt.

18 Por. Tomasz a Kempis, O naśladowaniu Chrystusa, III, rozdz. 5, Kraków 1981.

${ }^{19}$ Za: J. Aumann, Zarys historii..., dz. cyt., s. 199; por. B. Calati, R. Grégorie, A. Blasucci, Historia duchowości, tłum. K. Franczyk, J. Serafin, Kraków 2005, s. 310.

${ }^{20}$ Słowa św. Katarzyny ze Sieny.

${ }^{21}$ G.B.M. Contarini, Vita del B. Domenico..., dz. cyt.; por. R. Diaccini, Vita del..., dz. cyt., s. 21.

${ }^{22}$ R. Diaccini, Vita del..., dz. cyt., s. 28. 
czącego przed wizerunkiem Ecce Homo. Na klęczniku leżą Pismo Święte, czaszka oraz bicz ${ }^{23}$. Inny wizerunek ukazuje Dominika łączącego się z Chrystusem w bólu poprzez biczowanie $^{24}$.

W relacji Antonio Mongitorego z 1708 roku znajduje się opis obrazu ukazującego o. Dominika klęczącego przed wizerunkiem Ecce Homo, z koroną cierniową na głowie, biczem w ręku i ciężkim łańcuchem na szyi. Jego plecy ociekają krwią, a nad głową unosi się gołębica. Autor nazwał ten obraz antica imagine - stary wizerunek. Można więc wnioskować, że pochodził z okresu narodzin kultu bł. Dominika w zakonie kaznodziejskim. Każdy wymieniony element to nośnik informacji dotyczący o. Dominika. Wizerunek Ecce Homo, dyscyplina, łańcuch - wszystkie te składniki przypominają, że błogosławiony podejmował liczne umartwienia w duchu ekspiacji wobec Jezusa cierpiącego ${ }^{25}$. Pod wizerunkiem na obrazie umieszczony był łaciński napis: B.P.M. Dominicus Spadafora Nobilis Palermitanus mundanorum e vagina ereptus, exima penitentia perpolitus, scientia nitidus, Sanctitate, rutilans, ensis formidabilis Mundo, Carni et Daemoni effectus, miraculis coruscans in Coelum transfertur anno $1521^{26}$.

Dobrowolny post od Święta Podniesienia Krzyża do Wielkiej Niedzieli, piątek o chlebie i wodzie oraz włosienni-

${ }^{23}$ Obraz beatyfikacyjny (1920) w Monte Cerignone oraz wizerunek bł. Dominika - Archiwum S. Sabina - Rzym, obraz z Venetico Superiore i Palermo. Sztandar z podobizną bł. Dominika Spadafory oraz płaskorzeźba dłuta Angela Feduzziego.

${ }^{24}$ Tamże.

25 J. Marecki, L. Rotter, Jak czytać wizerunki świętych. Leksykon atrybutów i symboli hagiograficznych, Kraków 2009, s. 671-672 oraz 424.

${ }^{26}$ A. Mongitore, Vita del B. Domenico Spadafora Domenicano, [w:] Palermo..., dz. cyt. 
ca i wspomniane praktyki pokutne to formy okazania miłości Zbawicielowi ${ }^{27}$. Patrząc na Najświętsze Człowieczeństwo Jezusa, które stało się jedną raną - gdzie każda rana była wyrzutem, każdy ślad po biczu napomnieniem - Spadafora wzbudzał w sobie żal za grzechy, jakie popełniał człowiek. „Jeśli kto chce pójść za Mną, niech się zaprze samego siebie, niech weźmie krzyż swój i niech Mnie naśladuje. Bo kto chce zachować swoje życie, straci je; a kto straci swe życie z mego powodu, znajdzie je" (Mt 16, 24. 25). Twierdzenie, że utrata życia stanowi gwarancję innego, takiego, które się nigdy nie kończy, stanowi fundamentalną prawdę krzyża. Na nagrobku Spadafory wyryto epitafium: Sanguine clarus, doctrina clarior, sanctitate clarissimus - znakomity urodzeniem, jeszcze bardziej mądrością, a najbardziej świętością.

Błogosławiony Dominik Spadafora, ukształtowany we wspólnotach szerzących zasady obserwancji, wcielał w życie słowa ślubów: „posłuszeństwo Bogu, Najświętszej Maryi Pannie, św. Dominikowi”. Dla następnych pokoleń mieszkańców Monte Cerignone i całego terenu kwesty, był on symbolem maryjnej modlitwy, jaką jest różaniec. Modlitwa ta była odmawiana przy śmierci wiernych ${ }^{28}$. Również dzisiaj mieszkańcy tego regionu proszą o wstawiennictwo bł. Dominika w trudnych chwilach swego życia, modląc się i rozważając tajemnice różańca, a kościół Matki Bożej

27 D.M. Marchese, Vita del Beato Domenico Spadafora, [w:] Sacro Diario Domenicano, dz. cyt.; A. Mongitore, Vita del B. Domenico..., dz. cyt.; R. Diaccini, Vita del..., dz. cyt., s. 21, 28.

${ }^{28}$ C. Bialowas, Credere o non credere, cz. 2, Kraków 2006, s. 18; Fu proprio in quella occasione che, credendola morta, le donne del suo piccolo villaggio, si riunirono ed insieme le recitarono il Santo Rosario, chiedendo insieme ai familiari e ai parenti l'intercessione del nostro caro Beato Domenico. 
Łaskawej, który wybudował Dominik Spadafora, zyskał nazwę: Matki Bożej Różańcowej.

Ojciec Pio Forgione na swoim obrazku prymicyjnym napisał: „Jezu, moje pragnienie i życie moje, kiedy dziś drżący Cię unoszę w tajemnicy miłości, spraw, abym był dla świata drogą, prawdą, życiem, a dla Ciebie świętym kapłanem, ofiarą doskonałą". Podczas mszy świętej celebrowanej przez o. Pio wszyscy czuli, że prawdziwie z Chrystusem przeżywa mękę i przybicie do krzyża. W prywatnym objawieniu tak Pan Jezus o nim mówił: „Posiada moją władzę, ponieważ ja, Jezus, żyję w nim. (...) Jego gesty, słowa, spojrzenie dokonują więcej niż przemowa wielkiego mówcy. Ja nadaję wartość temu wszystkiemu, co z niego wychodzi. Jest arcydziełem mojego miłosierdzia. Jego obdarzyłem wszystkimi darami mojego Ducha. Jest moim doskonałym naśladowcą, moją Hostią, moim ołtarzem, moją ofiarą, moim upodobaniem, moją chwałą!" ${ }^{29}$.

Ojciec Jerzy Tomziński, przełożony generalny Zgromadzenia Ojców Paulinów, 21 września 1962 roku uczestniczył w mszy świętej odprawianej przez o. Pio. Wspomina, że tym, co najbardziej wtedy przeżył, był moment konsekracji: „Ojciec Pio zachowywał się tak, jakby widział Chrystusa. Oparł się na ołtarzu, ręce położył tak, jakby obejmował krzyż, i patrzył na Hostię. On widział Pana Jezusa, że cierpi, że umiera. Widział Go w Hostii - to się ujawniło w jego twarzy. To było coś nieprawdopodobnego. (...) Nie widziałem kapłana celebrującego, ale Mękę Pana Jezusa na Golgocie. Widziałem, że Pan Jezus cierpi i umiera, że krew się leje. Widziałem i przeżywałem, dzięki Ojcu Pio, niebo przy oł-

${ }^{29}$ Msza św. Ojca Pio, „Miłujcie się!” 4 (2006). 
tarzu"30. Zakonnik odczuwał prawdziwy, nienasycony głód Eucharystii $^{31}$. Po zakończeniu mszy świętej, leżąc przed ołtarzem, zatapiał się w krwawym misterium męki Pańskiej ${ }^{32}$, Chrystus pozwolił mu bowiem zbliżyć się do tajemnicy swojej śmierci, obdarzył o. Pio stygmatami. Pogrążony w modlitwie przyjmował w ten sposób Boży dar, by poświęcić siebie w intencji odkupienia kolejnych dusz. Należy jednak podkreślić, że nawet podczas mistycznego zatopienia w ekstatycznej modlitwie o. Pio nie przestawał prosić i wstawiać się za bliźnich. Tak też było, gdy złożony ciężką chorobą przebywał w kapucyńskim klasztorze w Venafro. W tym czasie duchową opiekę nad nim sprawował o. Agostino, który w swym duchowym Dzienniku spisywał wypowiadane przez o. Pio w mistycznej ekstazie słowa i modlitwy. Oto fragment jednej z nich: „O Jezu, polecam Ci tę osobę... nawróć ją, zbaw ją... nie tylko nawróć ją, ponieważ potem może utracić Twoją łaskę, ale zbaw ją, zbaw ją... czyż nie wylałeś za nią Twojej krwi" ${ }^{33}$. Zaskakujące jest podobieństwo przeżywania Eucharystii św. Franciszka, mówiącego o oczach duszy widzącej Chrystusa, Jego Ciało i Krew, a relacją osób uczestniczących w mszy sprawowanej przez o. Pio. Maria Winowska tak opisuje Eucharystię o. Pio w książce Prawdziwe oblicze Ojca Pio:

${ }^{30}$ Msza św. Ojca Pio, dz. cyt.

${ }^{31}$ W liście do o. Benedetta 29 marca 1911 roku o. Pio pisze o pragnieniu Najświętszego Sakramentu i radości, jaką odczuwa po Komunii.

${ }^{32}$ Tamże o. Pio pisze o rozmyślaniach o Męce Chrystusa.

33 B. Strzechmiński OFMCap, Za obojętnych i gorliwych, „Głos Ojca Pio" 57 (2009), https://glosojcapio.pl/modlitwa-ojca-pio/item/116-za-obojetnych-i-gorliwych (27.01.2019). 
Twarz jego przeobraża się, gdy stanął u stopni ołtarza. Nie trzeba być mędrcem, żeby zrozumieć, że znalazł się w świecie dla nas niedostępnym. Nagle pojmuję, dlaczego Msza odprawiana przez niego przyciąga tłumy, dlaczego je przykuwa i podbija. Od pierwszej chwili jesteśmy raptownie wciągnięci w głąb tajemnicy. Jak niewidomi otaczający widzącego. Jesteśmy bowiem ślepcami, przebywającymi za granicami rzeczywistości. To właśnie jest posłannictwem mistyków. Oni przywołują do życia nasze wewnętrzne oczy, które uległy zanikowi, oczy przeznaczone do oglądania olśniewającej jasności, nieporównywalnie potężniejszej od światła widzialnego okiem śmiertelnika ${ }^{34}$.

W kapłańskim życiu Ojca Pio była jedna modlitwa, pełne miłości wstawiennictwo dla zbawienia ludzi. Codziennie w zakrystii przed mszą świętą, w konfesjonale podczas spowiedzi, w ogrodzie lub klasztornych korytarzach w czasie odmawiania różańca czy wreszcie w trakcie odpisywania na listy - modlił się za tych, którzy za jego pośrednictwem polecali się Bożemu miłosierdziu. Wielu z nich nie znał ani nie spotkał, byli też i tacy, których udało mu się poznać tylko dzięki Bożej interwencji, o czym dał świadectwo 20 grudnia 1913 roku w jednym z listów do o. Benedetta:

Podczas modlitwy zdarza się, że zapominam modlić się za tych, którzy prosili mnie o modlitwy (nie o wszystkich jednak), albo za tych, za których zamierzałem się modlić. Zanim zacznę modlitwę, czynię wysiłek, aby polecić tę czy tamtą osobę. Lecz, o Boże! Skoro tylko wejdę w modlitwę, mój umysł staje się całkowicie pusty i nie pozostaje żaden ślad tego, co miałem bardzo mocno w sercu. W innych

${ }^{34}$ B. Strzechmiński OFMCap, Za obojętnych i gorliwych, dz. cyt. 
przypadkach natomiast czuję się pobudzony, aby modlić się za kogoś innego, za kogo nigdy nie zamierzałem się modlić, a co jeszcze cudowniejsze, za kogoś, kogo nigdy nie znałem ani nie widziałem, ani nie słyszałem, kto nigdy nie polecał się, nawet za pośrednictwem innych. Prędzej czy później Pan wysłuchuje zawsze tych modlitw.

Wchodzimy tu w zjawisko, którego skutki zaczął sobie o. Pio uświadamiać na początku kapłańskiego posługiwania. To dar modlitwy mistycznej, podczas której Bóg z taką intensywnością oddziaływał na stan jego duszy, iż o. Pio nie potrafił modlić się inaczej, jak tylko w taki sposób, na jaki pozwalał mu Duch Święty. Odnosi się to do treści modlitwy i osób, za które Bóg chciał, by się wstawiał ${ }^{35}$.

Giovanni Bucci, przyjaciel o. Pio, zapytał go kiedyś, jaką modlitwą modli się najczęściej: dyskursywną czy afektywną. Usłyszał wtedy następującą odpowiedź: „Ja nie znam się na modlitwach dyskursywnych i afektywnych. Żyję prosto, bez rozkładania wszystkiego na czynniki pierwsze: dziękuję, żałuję, upokarzam się - w sumie wracam do podstawowego pokarmu"36.

Jako przewodnik duchowy o. Pio wskazywał na pięć zasad wzrostu duchowego: cotygodniową spowiedź, codzienne przyjmowanie Komunii świętej, duchowe czytanie, medytację i rachunek sumienia. Spowiedź porównywał do cotygodniowego sprzątania pokoju. Zalecał, aby dwa razy dziennie odbywać medytację i robić rachunek sumienia: raz rano - jako przygotowanie, by zmierzyć się z trudnościami dnia, i raz wieczorem - jako spojrzenie w świetle łaski na przeży-

${ }^{35}$ Por. B. Strzechmiński OFMCap, Za obojętnych i gorliwych, dz. cyt.

${ }^{36}$ B. Strzechmiński OFMCap, Za obojętnych i gorliwych, dz. cyt. 
ty dzień. Na pytanie, jak praktycznie stosować wiedzę teologiczną, często odpowiadał swym znanym powiedzeniem: „Módl się, wierz i nie martw się”. Nauczał wiernych, by we wszystkim rozpoznawali Boga i pragnęli ponad wszystko pełnić Jego wolę.

Zdaniem o. Pio modlitwa winna być pokorna, ufna, stała i wierna. Musimy pamiętać o własnej nicości oraz wielkości i dobroci Boga. Ufać, gdyż Jezus jest dobry i nie będzie mógł nie wysłuchać modlitw. Czego może się bać dziecko w ramionach takiego Ojca? Któż silniejszy od Jezusa? Na podstawie długiego doświadczenia o. Pio stwierdzał, że Jezus nie odmawia niczego - pod warunkiem, że nie przestaje się Go o to prosić. Modlitwa winna być kierowana ku Bogu i Jemu służyć. Trzeba stanąć w obecności Boga i oddać Mu cześć, ponieważ On jest naszym Bogiem, a my jego stworzeniami. Nasza modlitwa, pełna wdzięczności, powinna wielbić i adorować Boga. Zdecydowanie najwięcej miejsca w Epistolario zajmuje modlitwa prośby. Najczęściej spotykamy zwrot: „Niech się dzieje wola Boga”. Ojciec Pio pragnie jedynie, by Boży plan Ojca wypełnił się na nim. Mało jest słów: „Jezu, kocham Cię...".

Ojciec Pio nie tylko modlił się, ale również wielokrotnie prosił o modlitwę. Najpierw kierował prośby do Boga, a potem do Jego stworzeń. Czasem prośba była stanowcza, z nutą groźby: „biada ci jeśli mi nie udzielisz tej łaski, bo nie dam nikomu spokoju, lub szantażu: ja też się wycofam i będę myślał tylko o sobie bez niepokojenia się o kogokolwiek"37.

Swymi modlitwami o. Pio obejmował dosłownie wszystkich. Prosił za Kościół święty, by Bóg go uświęcił, za pa-

${ }^{37}$ B. Strzechmiński OFMCap, Za obojętnych i gorliwych, dz. cyt. 
pieży, biskupów, kaznodziejów i kierowników dusz, osoby konsekrowane, by zbawiając siebie, starali się o zbawienie wiernych. Modlił się o rozkrzewienie wiary i tryumf Świętej Matki Kościoła. Wypraszał łaski żywym i zmarłym. Pragnął, by łaska zbawienia jak najszybciej stała się udziałem dusz cierpiących w czyśćcu. Ofiarował za dusze czyśćcowe stosowne odpusty, odprawiał msze święte. Powtarzał: „Módlcie się, módlcie się, módlcie się. Musimy opróżnić czyściec. Wszystkie dusze w czyśćcu muszą być uwolnione". Kiedy po reformie liturgii usunięto niektóre formy odpustów za dusze czyśćcowe, o. Pio ze smutkiem, ale wciąż zdecydowanie nawoływał: „A więc kto będzie myślał o tych świętych duszach? Wy usilnie módlcie się za nie". Sam odtąd za zbawienie dusz czyśćcowych odmawiał sześćdziesiąt całych różańców na dzieñen ${ }^{38}$. Ojciec Pio - więzień konfesjonału, mistyk, niosący z pokorą krzyż swych licznych cierpień, w dzienniku z 1929 roku zostawił nam informacje dotyczące codziennych modlitw. „Nie mniej niż cztery godziny medytacji o życiu naszego Pana: o narodzinach, męce i śmierci. Nowenny: do Matki Boskiej z Pompei, do św. Józefa, do św. Michała Archanioła, do św. Antoniego, do serafickiego ojca Franciszka, do Najświętszego Serca Jezusa, do św. Rity, do św. Teresy od Jezusa. Codziennie nie mniej niż pięć całych różańców"39. Dochodziły do tego modlitwy okresowe, jak nowenna do Dzieciątka Jezus przed Bożym Narodzeniem. Dodać do tego należy sprawowanie sakramentów i liturgię godzin. W czasie złej pory roku można go było znaleźć na

${ }^{38}$ B. Strzechmiński OFMCap, Za obojętnych i gorliwych, dz. cyt.

${ }^{39}$ A. Lamis, Zapiski kierownika duchowego Ojca Pio, red. G. di Flumeri, tłum. R.M. Hinc, Kraków 2017, s. 348-351, zawiera osiem stron dziennika o. Pio. 
modlitwie od około 4.30 do 9.30 rano, zaś codziennie we wszystkich porach roku od 22.45 aż do Ave Maria, czyli do północy. W jednym z listów święty pisał, że po dwudziestu godzinach pracy jego ramiona są słabe od ciągłego wznoszenia ich do nieba, by wydrzeć łaski od Pana.

Dla wierzących modlitwa jest darem łaski. Zakłada ona pewien wysiłek. Wielcy ludzie modlitwy Starego Przymierza przed Chrystusem, podobnie jak Chrystus, Matka Boża i święci pouczają nas, że modlitwa jest walką. Przeciw komu? Przeciw nam samym i przeciw podstępom kusiciela, który robi wszystko, by odwrócić człowieka od modlitwy, od zjednoczenia z Bogiem (por. KKK, n. 2612, 409). Modlimy się tak, jak żyjemy, ponieważ tak żyjemy, jak się modlimy. Jeśli nie chcemy stale postępować według Ducha Chrystusa, nie możemy także stale modlić się w Jego imię (por. KKK, n. 2015). „Duchowa walka” nowego życia chrześcijanina jest nieodłączna od walki modlitwy.

Warto jeszcze wspomnieć o znaczeniu śpiewu i muzyki w oddawaniu czci Bogu, ponieważ - jak twierdziła św. Hildegarda - muzyka to czyste wspomnienie raju, w którym Adam wraz z aniołami śpiewał psalmy na cześć Stwórcy ${ }^{40}$. Zarówno dla św. Franciszka, bł. Dominika czy św. o. Pio śpiew był bardzo ważny, stanowił integralną część Oficjum. Franciszek śpiewał, "grając” na dwóch kijach hymny po-

${ }^{40}$ http:/archiwum.rp.pl/artykul/135457-Muzyka-jestwspomnieniem-raju.html (dostęp: 1.03.2018).

32. Ks. dr Krzysztof M. Białowąs 
chwalne. „Albowiem muzyka zmiękcza twarde serca i wprowadza w nie wilgoć skruchy oraz przyzywa Ducha Świętego" - napisała św. Hildegarda w pierwszym swoim dziele. Świat, zarówno dla Hildegardy, jak i św. Franciszka, był hymnem, symfonią na cześć Boga Stwórcy.

Bardzo ważnym aspektem skuteczności modlitwy jest wspomniana wcześniej spowiedź. Catalina (Katya) Rivas, boliwijska mistyczka i stygmatyczka, pisała, że Pan Jezus i Matka Boża poprzez modlitwę pragną nauczyć nas owocnie uczestniczyć w tajemnicy naszej wiary. Pan Bóg pragnął podkreślić ważność sakramentu pojednania oraz ukazać całą prawdę o tym, co dokonuje się podczas każdej spowiedzi. Oto fragment wypowiedzi Cataliny:

Penitentka siedziała i spowiadała się, lecz nie przed księdzem, tylko przed samym Jezusem, który zajął miejsce kapłana. Widziałam postać Jezusa z boku. Podpierał brodę o złożone jak do modlitwy ręce i wsłuchiwał się uważnie. W pewnym momencie Jezus uniósł rękę i wyciągnął ją w kierunku dziewczyny, tak że prawie dotykał jej głowy. Dłoń Jezusa była pełna światła; wychodziły z niej złociste promienie, które padały na dziewczynę, okrywały ją swym blaskiem i przemieniały. Widziałam, jak z każdą chwilą zmieniała się jej twarz - tak, jakby ktoś zdejmował z niej maskę.

W chwili, w której Jezus udzielał dziewczynie rozgrzeszenia, Matka Boża uklękła i skłoniła głowę, a wszystkie postacie znajdujące się wokół niej zrobiły to samo. Jezus wstał, zbliżył się do penitentki, a ja dopiero wtedy mogłam zobaczyć, że na miejscu, na którym siedział, przez cały czas znajdował się kapłan. Pan Jezus objął dziewczynę i pocałował ją w policzek. Potem obrócił się, objął kapłana i także 
pocałował go w policzek. W tym momencie wszystko wypełniło się niezwykłym światłem, które zniknęło, unosząc się w górę, tak jak zniknęło również całe widzenie.

Pan Bóg obdarował mnie najpierw tym niezwykłym doświadczeniem mistycznym, a następnie wypowiedział te słowa: „Gdyby ludzie wiedzieli, jakiej przemiany doznaje dusza podczas dobrze odbytej spowiedzi, i zdawali sobie sprawę z obecności Ducha Świętego, który mieszka w niej na mocy łaski uświęcającej, przyjmowaliby ją na kolanach". Kiedy dziewczyna wyszła z pokoju, w którym się spowiadała, poczułam ogromne pragnienie, żeby przed nią uklęknąć. Uścisnęłam ją jednak tylko z całego serca; wiedziałam przecież, że przytulam osobę, którą wcześniej przytulił Jezus $^{41}$.

Dysertacja ta poświęcona jest modlitwie i świętości. Matka Teresa powtarzała, że świętość to nie jest luksus dla wybranych. To jest zadanie dla każdego z nas. Bardzo często mówiła o tym, żeby zaczynać dzień od uśmiechu. To jest właśnie takie dobro, którym możemy się dzielić z każdym i zawsze. Święta z Kalkuty była wielką realistką i powtarzała, że żeby kochać wszystkich, to trzeba umieć pokochać Chrystusa. To właśnie była jej droga do świętości.

Święci są przedstawicielami różnych stanów i narodów. Ich beatyfikacja lub kanonizacja ma wymiar socjologiczny, dogmatyczny idydaktyczny. Dlatego tak ważne jest, by osoby wynoszone na ołtarze były inspiracją, przemawiały do współczesnego człowieka, ożywiały jego wiarę. Szczególnie wymowne są słowa bł. kard. Schustera, arcybi-

${ }^{41}$ C. Rivas, Sakrament pojednania - pocałunek Jezusa, „Miłujcie się!” 5/2004, s. 29 - por. https://archiwum.milujciesie.org.pl/nr/temat_numeru/sakrament_pojednania_pocalunek_jezusa.html. 
skupa Mediolanu (którego beatyfikował nasz papież św. Jan Paweł II dnia 12 maja 1996 roku - 23 lata temu): „Ludzie nie dają się już przekonać naszym kazaniom, lecz w obliczu świętości jeszcze wierzą, jeszcze klękają, jeszcze się modlą. Gdy przechodzi święty, żywy czy zmarły, przychodzą wszyscy. (...) Diabeł nie lęka się naszych stadionów sportowych, naszych kin; on boi się naszej świętości. Błogosławię wam. Bądźcie święci”"

${ }^{42}$ Citterio B., I miei sette cardinali, Centro Ambrosiano, 2002, s. 61 . 